RESEARCH ARTICLE

\title{
Nutritional and Pharmacological Strategies of Bodybuilders in Preparation Period for Competition
}

\author{
Amanda Assenheimer ${ }^{1}$, Igor Brandão ${ }^{2}$, Mauricio Schüler Nin $^{3}$ and Rafael Longhi ${ }^{3^{*}}$ \\ ${ }^{1}$ Nutritionist, Centro Universitário Metodista IPA, Brazil \\ ${ }^{2}$ Professor, Centro Universitário AGES, Brazil \\ ${ }^{3}$ Professor, Centro Universitário Metodista IPA, Brazil
}

*Corresponding author: Prof. Dr. Rafael Longhi, Centro Universitário Metodista IPA, Coronel Joaquim Pedro Salgado Street, $N^{\circ}$ 80, Zip code: 90420-060, Brazil, E-mail: longhinutricao@gmail.com

\begin{abstract}
Introduction: Low-carb and high protein diets are common practices among bodybuilders although results in the literature are still sparse and controversial, in addition to the consumption of Anabolic Androgenic Steroids.

Objective: To analyze food and pharmacological consumption by bodybuilding athletes, in the period of preparation for competition.

Methods: This was a cross-sectional inferential study performed with athletes using the snowball method. The data were collected using a questionnaire of life habits and a 72 hours food survey.

Results: Fifteen athletes were evaluated: $60 \%(n=9)$ males and $40 \%(n=6)$ females, with a mean age of 27 years. Regarding nutrients, carbohydrates had a mean intake of 1.68 $\mathrm{g} / \mathrm{kg}$ body weight, mean protein content was $3.68 \mathrm{~g} / \mathrm{kg}$ body weight, and lipids were $20.4 \%$ of the Total Energy Value. Protein and lipid intakes were not statistically significant, but when the carbohydrate consumption was compared, there was a statistical difference between the sample values and the recommended ranges. The use of Anabolic Androgenic Steroids was cited by $65 \%$ of the sample studied, with the use of more than one type of drug.

Conclusion: The data found in this study suggest the necessity of a nutritional monitoring, specialized in this category, to guide and adapt the individualized nutritional needs of each athlete.
\end{abstract}

\section{Keywords}

Anabolic Androgenic Steroids, Performance, Macronutrients, Micronutrients, Resistance Training

\section{Introduction}

Bodybuilder is the term used to describe the athletes of high-intensity exercise with weights, which aim at modeling the body through the development of muscle mass [1]. Bodybuilding differs from most sports because the participant's physique, rather than athletic performance, is judged, and the ultimate goal of body builders is to achieve the large muscle mass that is defined and symmetrical [2], then the muscular size of the athlete between definition, proportion, symmetry, aesthetics and harmony [3].

To reach this level of competition, athlete's nutrition is critical during preparation because nutrients such as carbohydrates, lipids and proteins provide the energy to preserve bodily functions during rest and physical activity [4]. But it is important to note that, preparation for bodybuilding competition involves drastic reductions in body fat while maintaining muscle mass, in this way, competitors or amateurs typically achieved through decreased caloric intake, in many cases with a strong scientific basis; however, many do not [5].

Specifically, inadequate protein intake, besides not being a determining factor to improve athlete performance, may result in damage to the body due to renal and hepatic overload that this excess protein can cause [6]. Regarding carbohydrates and resistance training, the studies on the effects of carbohydrates restriction and performance are scarce and the evidence is controversial [7].

Citation: Assenheimer A, Brandão I, Nin MS, Longhi R (2018) Nutritional and Pharmacological Strategies of Bodybuilders in Preparation Period for Competition. Int J Sports Exerc Med 4:097. doi. org/10.23937/2469-5718/1510097

Accepted: July 07, 2018; Published: July 09, 2018

Copyright: (c) 2018 Assenheimer A, et al. This is an open-access article distributed under the terms of the Creative Commons Attribution License, which permits unrestricted use, distribution, and reproduction in any medium, provided the original author and source are credited. 
On the other hand, Anabolic Androgenic Steroids (AAS) supplementation is a widespread strategy among athletes and non-athletes alike who want to increase strength and muscle mass gain [8], with a worldwide prevalence rate of $6.4 \%$ in males and $1.6 \%$ in women [9], and according to $\mathrm{Yu}$, et al. [10], a large number of academic studies investigating the performance-enhancing effects of AAS have described discordant and often contradictory outcomes. It is important to highlight that the World Anti-Doping Agency (WADA) has been a prohibited list of AAS, which remain the most frequently detected class of doping agents in elite sport [11].

Based on these data, it is believed that the consumption of macronutrients and AAS during the preparation period for bodybuilding competition may be inadequate to that recommended by the International Society Sports Nutrition (ISSN) and American College of Sports Medicine (ACSM) (in this case, nutrients), as well as, the consumption of micronutrients from the diet, which are restricted during the pre-competition period, thus being supplemented in a synthetic way.

This article aims to describe and analyze the nutritional strategies adopted by bodybuilders of both sexes, based on scientific evidence during pre-competition. Data will be discussed separately for nutrition (macronutrients and micronutrients), pharmacological agents and supplements.

\section{Methods}

\section{Experimental procedures}

Since this is an observational study, the researchers were not responsible for the interventions. All data were provided by the participants before the competition. Bodybuilders were requested to describe in detail all their practices, diet, nutritional supplements and pharmacological agents.

\section{Participants}

Descriptive cross-sectional study with bodybuilding athletes from May to September of 2016, performed with bodybuilding athletes from Porto Alegre, Brazil, using the Snowball method with 15 athletes between 20 and 40-years-old, of both sexes. The interviewees were voluntarily submitted to the study, after being duly informed about the procedures and signing the respective Free and Informed Consent Term.

After the approval of the Ethics and Research Committee of the Centro Universitário Metodista - IPA, ( $\mathrm{N}^{\circ}$. 1.638.598), the study was initiated.

For the data collection, a questionnaire was applied, with 30 questions containing information on age, sex, weight, height, schooling, daily activities, time practicing bodybuilding, duration of training, frequency of training, bodybuilding goal, category duration of prepa- ration, duration of preparation, quality of sleep, chronic diseases, use of alcohol or tobacco, use of dietary supplements, frequency of fruit consumption, type $A$ and type $B$ vegetables, water consumption and use of anabolic steroids. In addition to the 72 hours food survey, alternating in two-week days and one weekend day.

The data were collected through the questionnaire, and later organized into a database. Food surveys were calculated using the Brazilian Food Composition Table [12].

Descriptive statistics were performed for the macro and micronutrient consumption data, as well as the anthropometric characteristics of the individuals analyzed. Likewise, an inferential statistical analysis was performed to compare the consumption of lipids, carbohydrates and proteins versus the recommendations of national and international agencies, by using the Z-test for parametric values. Prior to the Z-test, it was performed the Kolmolgorov-Smirnnov test to verify the normality and equality of variance. Absolute and relative frequencies were used to express the qualitative variables. For the quantitative variables, the mean, standard deviation and $95 \%$ confidence interval $(95 \% \mathrm{Cl})$ were calculated. To compile the data, Excel $^{\circledR}$ was used and the Sigma Stat $3.1^{\circledR}$ program was used for the inferential calculations. In the inferential analysis, the comparison test between the sample and recommendations data was used, and the $95 \% \mathrm{Cl}$ intervals were shown, being considered statistically significant differences when $P \leq 0.05$.

\section{Results}

The sample consisted of 15 athletes, $60 \%(n=9)$ males and $40 \%(n=6)$ females, with a mean age of 27.7 \pm 4.1 years. As for the other anthropometric variables, the mean weight for men was $88.2 \pm 15.1 \mathrm{~kg}$ on average, and for women, the mean was $60.8 \pm 8.4 \mathrm{~kg}$, while the mean height for men was $172.8 \pm 6.1 \mathrm{~cm}$, and for women $160.6 \pm 5.4 \mathrm{~cm}$. The percentage of body fat for men averaged $8.4 \pm 2.8 \%$, and for women the mean was 10.2 $\pm 6.2 \%$, showing no statistically significant difference ( $P$ $=0.458)$.

In addition to anthropometric results, questions related to the interviews diet were evaluated. Figure 1 shows the frequency of fruit consumption by bodybuilding athletes. In $74 \%$ of the sample, fruit consumption was reported, and daily consumption in the diet was $47 \%, 3$ to 6 times a week was cited by $7 \%$ of respondents, 2 times a week by $20 \%$, and no $27 \%$ of the sample. In relation to the consumption of type A vegetables (vegetables with up to $5 \%$ carbohydrates in their composition) and type B (vegetables with up to $10 \%$ carbohydrates in their composition), participants consumed, respectively, $4.6 \pm 3.1$ and $3.5 \pm 3.0$ times per week.

The mean carbohydrate intake by the sample was $1.38 \pm 0.51 \mathrm{~g} / \mathrm{kg}$ body weight. When compared to the recommended ranges in the literature, both the ACSM 


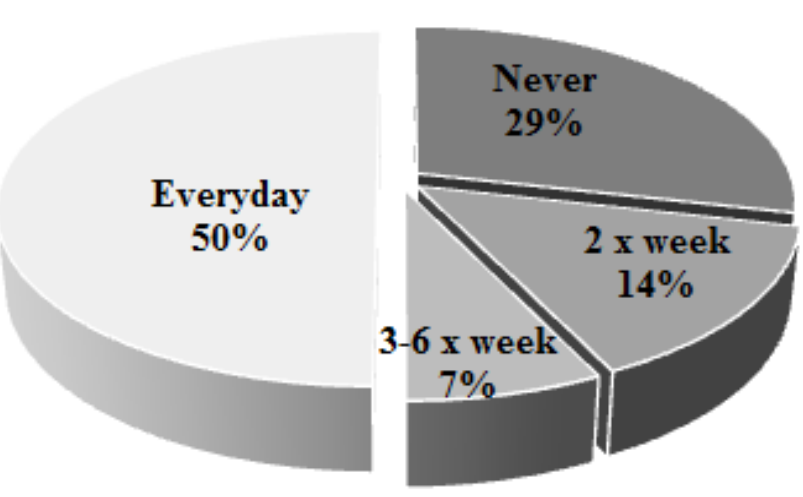

Figure 1: Frequency of fruit consumption in the week.

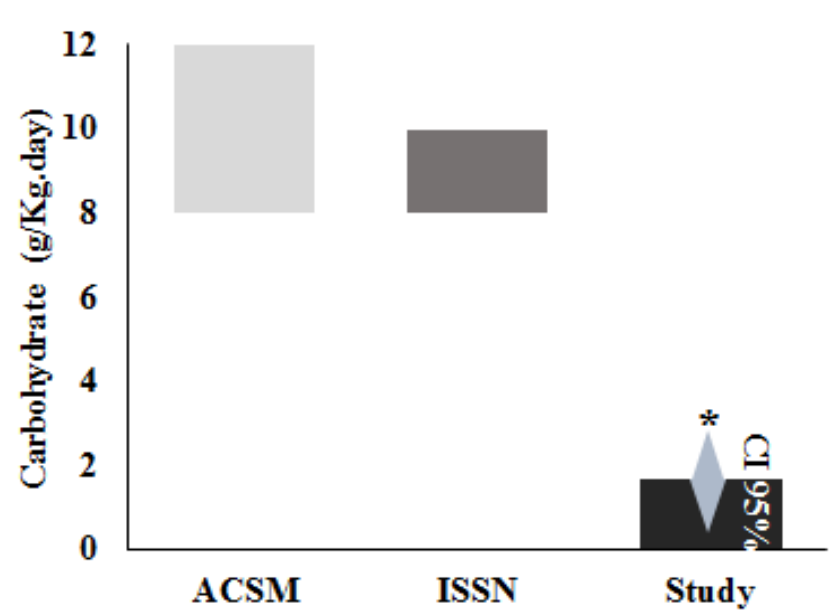

Figure 2: Comparison between the carbohydrate values of the study sample versus data recommended by ACSM and ISSN. Performed z-test and presented the 95\% confidence interval for the sample data. *It means that a statistically significant difference was found when compared with both reference values $(P<0.001)$.

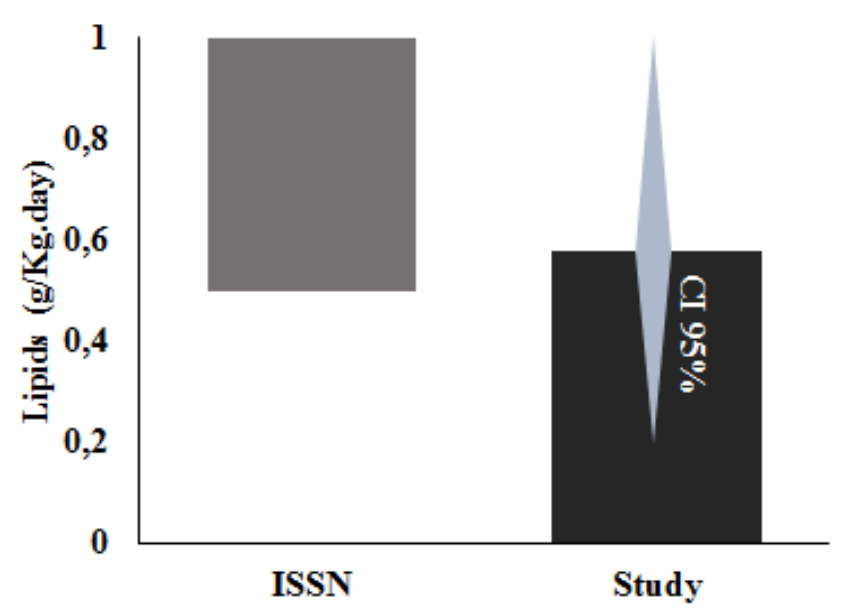

Figure 3: Comparison between the lipid values of the study sample versus data recommended by ISSN. Performed z-test and presented the $95 \%$ confidence interval for the sample data. There was no statistically significant difference $(P<0.05)$.

of 8 to $12 \mathrm{~g} / \mathrm{kg}$ body weight and the ISSN of 8 to $10 \mathrm{~g} / \mathrm{kg}$ body weight, the values resulted in a statistically significant difference for both protocols $(P<0.001$, Figure 2$)$.

The lipid intake by the sample had an average of 0.5 $\pm 0.5 \mathrm{~g} / \mathrm{kg}$ body weight, when compared to the ranges

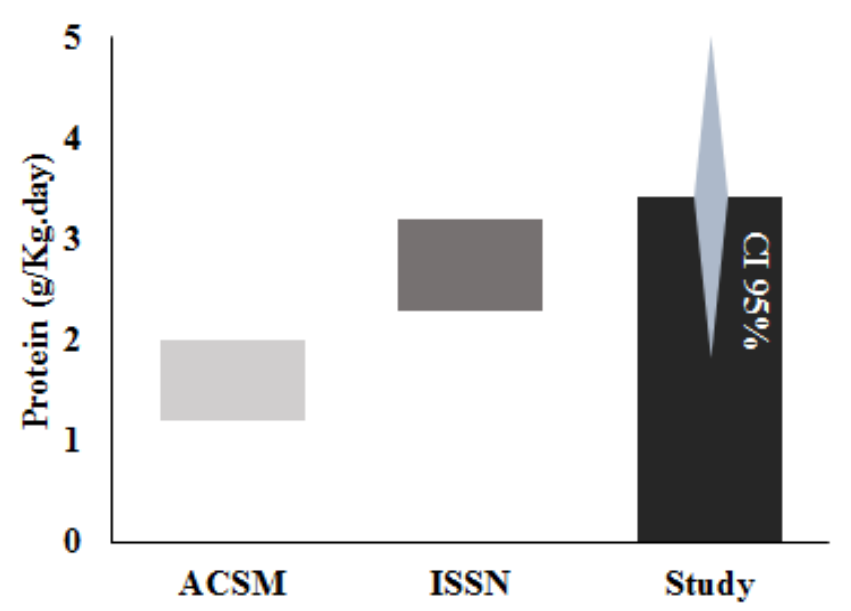

Figure 4: Comparison between protein values of the study sample versus data recommended by ACSM and ISSN. Performed z-test and presented the 95\% confidence interval for the sample data. There was no statistically significant difference $(P<0.05)$.

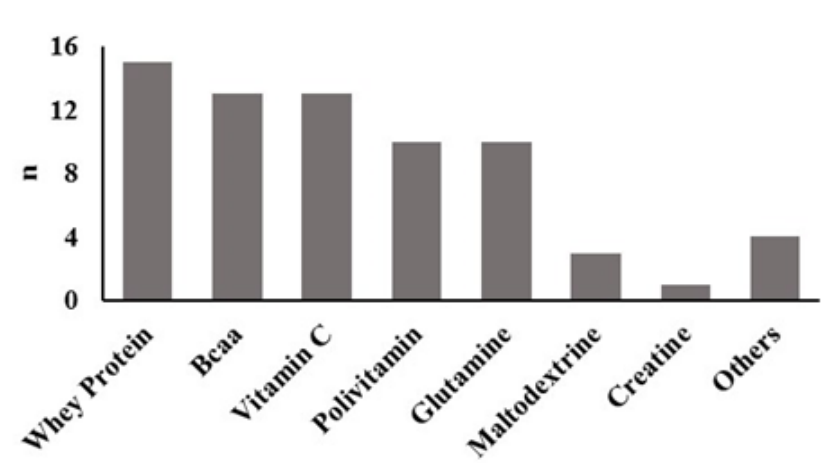

Figure 5: Consumption of food supplements by participants $(n=16)$. BCAA (branched-chain amino acids) Others = other supplements not revealed by the participants.

recommended by the ISSN literature of $0.5-1.0 \mathrm{~g} / \mathrm{kg}$ body weight. There was no statistically significant difference for this comparison ( $P>0.05$; Figure 3$)$. The ACSM presents values in percentage of VET, so they were not compared with the sample data in this reference unit. The same result was found when comparing protein intake by the sample, where the mean was $3.4 \pm 0.8 \mathrm{~g} / \mathrm{kg}$ body weight, compared to the recommended ranges in the ACSM literature from 1.2 to $2.0 \mathrm{~g} / \mathrm{kg}$ and ISSN of 2.3$3.1 \mathrm{~g} / \mathrm{kg}(P>0.05$; Figure 4).

In relation to Figure 5 the result shows the use of supplements most consumed by the sample, the main compound was Whey Protein, consumed by $94 \%$ of the participants evaluated. In the comparison between men and women regarding the use of different types of supplements, men showed a greater variety of use (men: $5.2 \pm 0.8$, women: $3.7 \pm 1.0, P=0.007$ ). Regarding the use of anabolic steroids, one of the participants did not respond to the questionnaire, and among the 15 respondents, $60 \%$ had already used it. Of the $60 \%$ who have used anabolic agents, the mean number of different drugs already used was 4.2 drugs/person, and the drugs used are shown in Table 1 . The age revealed 
Table 1: Frequency of use of drugs considered as anabolic by the participants.

\begin{tabular}{|l|l|l|l|}
\hline Drug & Therapeutic Class & $\mathbf{f}$ & $\mathbf{f r}$ \\
\hline Oxandrolone & AS & 5 & $33 \%$ \\
\hline Estanazole & AS & 5 & $33 \%$ \\
\hline Testosterone & AS & 5 & $33 \%$ \\
\hline Trenbolone & AS & 5 & $33 \%$ \\
\hline Boldenone & SM & 4 & $27 \%$ \\
\hline Growth hormone & Horm. & 2 & $13 \%$ \\
\hline Mesterolone & AS & 2 & $13 \%$ \\
\hline Nandrolone & AS & 2 & $13 \%$ \\
\hline Metonolone & AS & 2 & $13 \%$ \\
\hline Oxymetholone & AS & 1 & $7 \%$ \\
\hline
\end{tabular}

AS: Anabolic Steroid; SM: Sympathomimetic; Horm: Anabolic hormone not steroid; $f=$ absolute frequency; $f r=$ relative frequency.

by the participants as being the first time they used anabolic steroids was $23.4 \pm 5.4$ years and had used 2.4 \pm 2.2 times these drugs previously. Regarding the side effects presented by these drugs, 33\% reported having perceived some effect that linked to the use, from fever to acute myocardial infarction. Still, of these 33\%, less than half reported using some medication to reverse the side effects, and the common substance was anastrazol. In the comparison between men and women, there was no statistically significant difference in the number of times they had used these drugs $(P=0.420)$; however, the variety of anabolic agents already used in life by men outnumbers women (men: $3.9 \pm 3.4$, women: $0.7 \pm$ $0.8, P=0.045)$.

The analysis of the diet showed Vitamin C and Calcium values from the diet, respectively, $84.0 \pm 52.6$ and $340.6 \pm 129.2 \mathrm{mg} /$ day, with $75 \%$ of the participants using multivitamins at least 1 time per day, and almost all used supplements with vitamin C (94\%).

\section{Discussion}

It is important to highlight that all data were provided by the participants in the cut-off phase, in other words, in the weeks before the competition in which it is oriented for a decrease in body fat [2].

\section{Participants profile}

Regarding the anthropometric profile of the female sample, the average percentage of $10.1 \%$ body fat was highlighted. Similar results were found in a study by Van Der Ploeg, et al. [13], when 5 competitive bodybuilders were evaluated, which showed a significant decrease in body fat percentage. At the end of 6 weeks of intervention the athletes presented an average of $12.7 \%$ body fat. Regarding the male group, it is important to highlight that the lack of appropriate anthropometric references may lead these individuals to be mistakenly considered to be overweight or malnourished [14]. Da Silva, et al. [15] obtained a $9.7 \%$ body fat percentage in a sample of Brazilian bodybuilders, corroborating with the results of the present study, which obtained a mean of $8.3 \%$ body fat.

\section{Nutrition}

In relation to fruits and vegetables consumption, our results disagree with current literature, because according to Wang, et al. [16] the average consumption of fruits and vegetables should be around 5 portions per day so that there is a decrease in the factors of mortality risk from all causes. According to the present study, $46 \%$ of participants consumed fruits daily in the diet, but only 2 portions per day, 7\% consume 3 to 6 times per week, $20 \%$ of respondents 2 times per week and no day of the week was said by $27 \%$ of respondents. Important to comment that $26.7 \%$ of those interviewed said they did not consume any portion of fruit per day. According to Miller, et al. [17], the association between intake of fruits, vegetables, and legumes with cardiovascular disease and deaths has been investigated extensively around the world and the last results show that benefits appear to be maximum for both non-cardiovascular mortality and total mortality at three servings per day (equivalent to $375-500 \mathrm{~g} /$ day).

According to the ISSN, the proper intake of carbohydrates varies from 8 to 10 grams per kilogram of weight per day [18]. In the present study, the mean intake of the sample was around $1.68 \mathrm{~g} / \mathrm{kg}$ body weight, which was much lower than that recommended by the ISSN, as well as that recommended by the American College of Sports Medicine (ACSM) of 8 to 12 grams per kilogram of weight per day [19], considering that the average weight of the interviewees was between $88.2 \mathrm{~kg}$ (men) and $60.8 \mathrm{~kg}$ (women), the interviewers did not reach $150 \mathrm{~g}$ of carbohydrates per day. For example, a diet containing 200 grams of carbohydrate might be classified as moderately low for a 2,000-calorie intake, moderate carbohydrate at 1,500 calories and high-carbohydrate at 1,200 calories [20], in our study the mean values of ingested calories were 2177,4 calories (in both men and women), in this way, low carbohydrate diet was consumed for our participants.

Corroborating, Mitchell, et al. [21], analyzed natural male bodybuilders, their results showed a large reduction in total and free testosterone and Insulin-like Growth Factor-1 (IGF-1) occurred between PRE16 and PRE1 (weeks of training before competition). The authors comment about the reduction in anabolic hormone concentration is likely attributable to the prolonged negative energy balance, despite a high dietary protein intake, the same nutritional strategies adopted for our participants.

According to Mergenthaler, et al. [22] brain tissue represents around $2 \%$ of all body weight, but its glucose consumption reaches $20 \%$ of the total glucose energy of the diet, making this tissue the main consumer of glucose.

Ratifying the importance of this nutrient to resistance exercise, Haff, et al. [23] review the importance of carbohydrates in the performance of athletes from the scientific literature and concluded that athletes who are 
engaged in high intensity exercises should be advised to carbohydrate intake before, during, and immediately after exercise. The importance of carbohydrates was also cited in an article published by Baty, et al. [24], suggesting the consumption not only of proteins but proteins and carbohydrates with the goal of reducing muscle damage and fatigue.

In the present study, the mean protein intake by the sample was above the recommended level, $3.7 \mathrm{~g} /$ kg body weight, showing a tendency of the interviewers to consume hyperproteic diets, although it was not statistically significant, and the recommended ranges for high performance athletes are between 1.2 and 3.1 $\mathrm{g} / \mathrm{kg}$ body weight according to the used methodology, which would be sufficient to meet human needs, even in athletes seeking muscle hypertrophy, which is sufficient to meet human needs, even in athletes who seek muscular hypertrophy [25]. In a study conducted by Cyrino, et al. [26], muscle strength and development were analyzed in athletes who consumed amounts of protein between 1.5 and $2.5 \mathrm{~g} / \mathrm{kg}$ body weight associated with weight training and were able to conclude that this protein intake may contribute significantly to the increase of strength and muscle mass. However, the risks of consuming high amounts of proteins are known, Delimaris, et al. [27], attentive to the low efficiency of the organism in metabolizing the excess protein, which can cause a metabolic load in the bones, kidneys and liver. In addition, high-protein diets may also be associated with an increased risk of coronary heart disease due to intake of saturated fat and cholesterol.

When evaluated the consumption of supplements, $100 \%$ of our sample referred to the consumption of at least 2 dietary supplements; our data agree with those published by Hirschbruch, et al. [28] in which men had the highest consumers and supplements most cited in our research are in agreement with the aforementioned author. On the other hand, Fahy, et al. [29] point out that sportsmen are the largest consumers of supplements. In their results, $60.5 \%$ of women have never used any nutritional supplement. In the present study, we found a greater variety of supplements used by men, even though both sexes used some type of dietary supplement.

On the other hand, the consumption of vitamin $C$ in the present study, considering as its source only foods from the diet reported in the food survey, the daily recommendation (RDA) of $90 \mathrm{mg}$ for men and $75 \mathrm{mg}$ for women was adequate. In addition, $93.3 \%$ of athletes reported using vitamin $\mathrm{C}$ supplementation. In a study by Kreider, et al. [30] for well-nourished athletes, vitamin C supplementation does not seem to improve physical performance. However, there is some evidence that vitamin $\mathrm{C}$ (eg $500 \mathrm{mg} /$ day) after intense exercise may decrease the incidence of respiratory tract infections. Vitamin $C$ is also a precursor of oxalate, liable to produce hyperox- aluria, according to Rathi, et al. [31]. Corroborating, an important review about this topic, 40,536 men in the Health Professionals Follow-up Study during median follow-up of 11.3-11.7 years were significantly associated with a higher risk of incident kidney stones [32].

Regarding calcium intake, in the present study calcium from the diet reported in the food survey was relatively below the daily recommendation (RDA) of 1000 $\mathrm{mg}$ (340.6 $\pm 129.2 \mathrm{mg} /$ day). It is known the importance of this mineral in the process of contraction of the skeletal muscle, because it activates the attractive forces between the myosin and actin filaments, responsible for the contraction itself [33]. Corroborating, data from the seventies testify about the importance of calcium for muscle contraction, several authors show that calcium is part of the basic structure mechanism in the regulation of muscle contraction [34,35]. It has been hypothesized that calcium may lead to Interleukin-6 (IL-6) gene transcription, being released from the lateral sacs of the sarcoplasmic reticulum to activate IL-6 through activation of nuclear factor of activated T cells, in this way, IL-6 acts in an autocrine or paracrine manner, to increase glucose uptake and fat oxidation, and is also known to increase hepatic glucose production during exercise or lipolysis in adipose tissue. Finally, this same research comment about the use of oral supplementation with vitamins $C$ and $E$ for 4 weeks, as result, the IL- 6 net release from the exercising legs was almost blocked completely, attesting the importance to maintain studies about the possible toxic effect from vitamin C and performance [36].

Another point that shows the importance of these data refers to the relationship of this mineral with Cardiovascular Diseases (CVD). Huang, et al. [37] conclude in their review on the topic that low-dose calcium consumption increases cardiovascular risk, suggest that an inappropriate intake of calcium may be the trigger for the inflammatory response, which has been implicated in pathogenesis of CVD. In addition to cardiovascular risk, Peterlik, et al. [38] have shown a relationship between low calcium consumption with osteoporosis, colorectal cancer and breast cancer in addition to an increased risk of hypertension. In another study, a meta-analysis published by Wang, et al. [16], the authors conclude from 11 prospective studies with 12 independent cohorts involving more than 755,000 participants that low intakes of calcium are associated with cardiovascular mortality, with supplementation as a possible aggravating factor in this process.

Concluding and ratifying the importance of this paper in this field of research, Spendlove, et al. [39] comment in a robust systematic search that the majority of studies fail to provide detailed information on dietary supplementation and how this contributes to energy, macro, and micronutrient intake, in the opposite of present article.

\section{Pharmacological agents}

Finally, it's important to highlight that the consump- 
tion of anabolic steroids is not a single practice for elite athletes who seek to improve their performance in the sport they practice. Parkinson and Evans, et al. [40] carried out a study with 500 individuals using this substance, and found that four out of five steroid users were athletes, recreational bodybuilders, and non-athletes. The reasons for the administration were aesthetic with the sole intention of improving physical appearance. In the present work the sample has a different profile, since they are bodybuilders, but only $60 \%$ reported using it.

In a study of bodybuilders in Iran, a considerably smaller consumption (26.5\%) was observed and had a greater inversely proportional use to the time of formal education [41]. Already in another study, however, carried out in Brazil, a use in the life of $33.3 \%$ of AAS was found [42]. The results are very varied according to the methodology of information collection and target audience. In a study conducted in Iranian athletes was found a percentage of lifetime use of $72.8 \%$ [43]. In the latter study, testosterone was the most prevalent drug among AAS, which agrees with the results of the present study, where testosterone, along with three other substances, were the most commonly used drugs.

\section{Conclusion}

It was observed that the sample was characterized by the low consumption of carbohydrates and micronutrients important for the performance, besides the consumption of anabolic steroids. This high prevalence of anabolic steroids was found among the participants, with a greater variety of drugs used by men. Similarly, men have a higher frequency of consumption of dietary supplements than women, with a high overall prevalence.

This study has limitations related to the size of the sample, so the future perspectives of our team is to evaluate a larger sample size, besides verifying the possible side effects to the use of these substances and propose therapeutic strategies to reduce the use of these drugs while maintaining the performance of these athletes. Therefore, the data found in this study suggest the need for a nutritional monitoring specialized in high performance sports to guide and adjust the individualized nutritional needs of each athlete, as well as the continuity of research in this field to seek new scientific evidence.

\section{Conflict of Interest}

The authors declare no conflict of interest.

\section{Acknowledgments/Grant Support}

This study was supported by Centro Universitário Metodista/IPA and Universidade Federal do Sergipe (UFS).

\section{References}

1. Jorge Alberto Bernstein I,Tarcísio Matos de A (2002) Musculação, uso de esteróides anabolizantes e percepção de risco entre jovens fisiculturistas de um bairro popular de Salvador, Bahia, Brasil. Cad Saúde Pública 18: 1379-1387.
2. Gentil P, Andre Barbosa de Lira C, Paoli A, Alexandre Barbosa dos Santos J, Deivide Teixeira da Silva R, et al. (2017) Nutrition, pharmacological and training strategies adopted by six bodybuilders: case report and critical review. Eur $\mathrm{J}$ Transl Myol 27: 6247.

3. Pagnani A, Monteiro A. Culturismo e Musculação. In: DA COSTA, Lamartine (Org.). Atlas do Esporte no Brasil: Atlas do Esporte, Educação Física e Atividades Físicas de Saúde e Lazer no Brasil. [s.I.: s.n., s.d.] 401-402.

4. Mcardle WD, Karch FI, Karch VL (2011) Fisiologia do Exercício: nutrição, energia e desempenho humano. ( $\left.7^{\text {th }} \mathrm{edn}\right)$, Rio de Janeiro, Guanabara Koogan.

5. Helms ER, Aragon AA, Fitschen PJ (2014) Evidence-based recommendations for natural bodybuilding contest preparation: nutrition and supplementation. J Int Soc Sports Nutr 11: 20.

6. Heloisa T, Simon Rufatto R, Francisco Stefani A (2009) Avaliação nutricional e autopercepção corporal de praticantes de musculação em academias de Caxias do SulRS. Rev Bras Med Esporte 15: 291-294.

7. Meirelles CM, Gomes PSC (2016) Effects of short-term carbohydrate restrictive and conventional hypoenergetic diets and resistance training on strength gains and muscle thickness. J Sports Sci Med 15: 578-584.

8. Neto OB (2017) Long-term anabolic steroids in male bodybuilders induce cardiovascular structural and autonomic abnormalities. Clin Auton Res 1-14.

9. Nieschlag E, Vorona E (2015) Doping with anabolic androgenic steroids (AAS): Adverse effects on non-reproductive organs and functions. Rev Endocr Metab Disord 16: 199-211.

10. Yu JG, Bonnerud $P$, Eriksson A, Stål PS, Tegner $Y$, et al. (2014) Effects of long term supplementation of anabolic androgen steroids on human skeletal muscle. PLoS One 9: e105330.

11. Geyer H, Schänzer W, Thevis M (2014) Anabolic agents: recent strategies for their detection and protection from inadvertent doping. Br J Sports Med 48: 820-826.

12. nepa - Unicamp (2011) Tabela brasileira de composição de alimentos - TACO. ( $4^{\text {th }}$ edn $)$, Rev Campinas.

13. van der Ploeg GE, Brooks AG, Withers RT, Dollman J, Leaney F, et al. (2001) Body composition changes in female bodybuilders during preparation for competition. Eur $\mathrm{J}$ Clin Nutr 55: 268-277.

14. Maesta N, Cyrino ES, Junior NN, Morelli MYG, Sobrinho JMS, et al. (2000) Antropometria de Atletas Culturistas em Relação à Referência Populacional. Rev Nutr 13: 135-141.

15. Da silva PRP, De souza TR, De rose EH (2003) Composição corporal, somatotipo e proporcionalidade de culturistas de elite do Brasil. Rev Bras Med Esporte 9: 403-407.

16. Wang X, Ouyang Y, Liu J, Zhu M, Zhao G, et al. (2014) Fruit and vegetable consumption and mortality from all causes, cardiovascular disease, and cancer: systematic review and dose-response meta-analysis of prospective cohort studies. BMJ 349: 4490.

17. Miller V, Mente A, Dehghan M, Rangarajan S, Zhang X, et al. (2017) Fruit, vegetable, and legume intake, and cardiovascular disease and deaths in 18 countries (PURE): a prospective cohort study. Lancet 390: 2037-2049.

18. Kerksick CM, Arent S, Schoenfeld BJ, Stout JR, Campbell B, et al. (2017) International society of sports nutrition position stand: nutrient timing. Journal of the International Society of Sports Nutrition 14: 33. 
19. American College of Sports Medicine (2000) Joint Position Statement: nutrition and athletic performance. American College of Sports Medicine, American Dietetic Association, and Dietitians of Canada. Med Sci Sports Exerc 32: 21302145.

20. Wylie-Rosett J, Aebersold K, Conlon B, Isasi CR, Ostrovsky NW (2013) Health effects of low-carbohydrate diets: where should new research go? Curr Diab Rep 13: 271-278.

21. Mitchell L, Slater G, Hackett D, Johnson N, O'connor H (2018) Physiological implications of preparing for a natural male bodybuilding competition. Eur J Sport Sci 18: 619-629.

22. Mergenthaler P, Lindauer U, Dienel GA, Meisel A (2013) Sugar for the brain: the role of glucose in physiological and pathological brain function. Trends Neurosci 36: 587-597.

23. Haff GG, Lehmkuhl MJ, McCoy LB, Stone MH (2003) Carbohydrate supplementation and resistance training. $J$ Strength Cond Res 17: 187-196.

24. Baty JJ, Hwang H, Ding Z, Bernard JR, Wang B, et al. (2007) The effect of a carbohydrate and protein supplement on resistance exercise performance, hormonal response, and muscle damage. J Strength Cond Res 21: 321-329.

25. Hernandez AJ, Nahas RM (2009) Modificações dietéticas, reposição hídrica, suplementos alimentares e drogas: comprovação de ação ergogênica e potenciais riscos para a saúde. Rev Bras Med Esporte 15: 3-12.

26. Cyrino ES, Maestá N, Burini RC (2000) Aumento de força e massa muscular em atletas de culturismo suplementados com proteína. Revista Treinamento Desportivo 5: 9-18.

27. Delimaris I (2013) Adverse Effects Associated with Protein Intake above the Recommended Dietary Allowance for Adults. ISRN Nutr 2013: 126929.

28. Hirschbruch MD, Fisberg M, Mochizuki L (2008) Consumo de suplementos por jovens frequentadores de academias de ginástica em São Paulo. Revista Brasileira de Medicina do Esporte.

29. Fayh AP, da Silva CV, de Jesus FRD, Costa GK (2013) Consumo de suplementos nutricionais por frequentadores de academias da cidade de Porto Alegre. Rev Bras Ciênc Esporte 35: 27-37.

30. Kreider RB, Wilborn CD, Taylor L, Campbell B, Almada AL, et al. (2010) ISSN exercise \& sport nutrition review: research \& recommendations. J Int Soc Sports Nutr 7: 7.
31. Rathi S, Kern W, Lau K (2007) Vitamin C-induced hyperoxaluria causing reversible tubulointerstitial nephritis and chronic renal failure: a case report. J Med Case Rep 1: 155.

32. Ferraro PM, Curhan GC, Gambaro G, Taylor EN (2016) Total, dietary, and supplemental vitamin $C$ intake and risk of incident kidney stones. Am J Kidney Dis 67: 400-407.

33. Guyton AC, Hall JE (2006) Tratado de Fisiologia Médica. $\left(11^{\text {th }}\right.$ edn), Elsevier, Brasil.

34. Jiang $H$, Stephens NL (1994) Calcium and smooth muscle contraction. Mol Cell Biochem 135: 1-9.

35. Wakabayashi T (2015) Mechanism of the calcium-regulation of muscle contraction-In pursuit of its structural basis - Proceedings of the Japan Academy. Series B, Physical and Biological Sciences 91: 321-350.

36. Pedersen BK, Febbraio MA (2008) Muscle as an endocrine organ: focus on muscle-derived interleukin-6. Physiol Rev 88: $1379-1406$.

37. Huang JH, Tsai LC, Chang YC, Cheng FC (2014) High or low calcium intake increases cardiovascular disease risks in older patients with type 2 diabetes. Cardiovasc Diabetol 13: 120.

38. Peterlik M, Kállay E, Cross HS (2013) Calcium nutrition and extracellular calcium sensing: relevance for the pathogenesis of osteoporosis, cancer and cardiovascular diseases. Nutrients 5: 302-327.

39. Spendlove J, Mitchell L, Gifford J, Hackett D, Slater G, et al. (2015) Dietary Intake of Competitive Bodybuilders. Sports Med 45: 1041-1063.

40. Parkinson AB, Evans NA (2006) Anabolic androgenic steroids: a survey of 500 users. Med Sci Sports Exerc 38: 644651.

41. Nakhaee MR, Pakravan F, Nakhaee N (2013) Prevalence of use of anabolic steroids by bodybuilders using three methods in a city of iran. Addict Health 5: 77-82.

42. Santos AM, da Rocha MS, da Silva MF (2011) Illicit Use and Abuse of Anabolic-Androgenic Steroids Among Brazilian Bodybuilders. Subst Use Misuse 46: 742-748.

43. Rezaei SMA (2017) Study the Prevalence of Anabolic Steroids Consumption among Bodybuilding Athletes in Yasuj, Iran. Int J Nutr Sci 2: 103-108. 